\title{
Insulin-Like Growth Factor-I Induces Androgen Receptor Coactivator Expression in Skeletal Muscle Cells through the p38 MAPK and ERK1/2 Pathways
}

\author{
Chan Ho Park'2, Hye Jin Kim', Tae Un Kim² and Won Jun Lee** \\ ${ }^{1}$ Department of Exercise Science, College of Health Sciences, Ewha Womans University, 120-750 Seoul, Korea \\ ${ }^{2}$ Department of Physical Education, Pusan National University, Busan 609-736, Korea
}

Received October 15, 2010 /Accepted November 17, 2010

\begin{abstract}
Although insulin-like growth factor-I (IGF-I) and androgen receptor (AR) coactivators are well known effectors of skeletal muscle, the molecular mechanism by which signaling pathways integrating AR coactivators and IGF-I in skeletal muscle cells has not been previously examined. In this study, the effects of IGF-I treatment on the gene expression of AR coactivators in the absence of AR ligands and the roles of the p38 MAPK and ERK1/2 signaling pathways in IGF-I-induced AR coactivators induction were examined. C2C12 cells were treated with $250 \mathrm{ng} / \mathrm{ml}$ of IGF-I in the presence or absence of specific inhibitors p38 MAPK (SB203580) or ERK1/2 (PD98059). Treatment of C2C12 cells with IGF-I resulted in increased in GRIP-1, SRC-1, and ARA70 protein expression. The levels of GRIP-1, SRC-1, and ARA70 mRNA were also significantly increased after $5 \mathrm{~min}$ of IGF-I treatment. IGF-I-induced AR coactivator proteins were significantly blocked by pharmacological inhibitors of p38 MAPK and ERK1/2 pathways. However, there was no significant effect of those inhibitors on IGF-I-induced mRNA level of AR coactivators, suggesting that AR coactivators are post-transcriptionally regulated by IGF-I. Furthermore, the present results suggest that IGF-I stimulates the expression of AR coactivators by cooperative activation of the p38 MAPK and ERK1/2 pathways in C2C12 mouse skeletal muscle cells.
\end{abstract}

Key words : IGF-I, androgen receptor coactivator, p38 MAPK, ERK1/2, C2C12 skeletal muscle cell

\section{서 론}

엔드로젠(androgen)은 근육과 빼를 비롯한 체내의 다양 한 조직들에 있어 동화작용(anabolic effect)을 하며 특히 골 격근의 발달, 크기 및 부피 유지에 매우 중요한 물질이다 [1,3]. 엔드로젠 수용체는 핵 수용체과(nuclear receptor super-family)의 하위구성원인 스테로이드 수용체(steroid receptor)에 속하며[23], 대표적인 리간드 의존적 전사인자 (ligand-dependent transcriptional factor)로써 자신의 리간 드인 엔드로젠과의 결합 이후 그 생물학적 기능을 수행한다 [3]. 엔드로젠 수용체는 비활성 상태, 즉 리간드와 결합 전 상태에는 복합체(complex)를 형성하여 세포질(cytoplasm)에 존재하고 있다가 리간드와 결합 이후 HSPs를 분리시키고 핵으로 이동(translocation)하여 DNA 내에 엔드로젠 수용체 를 인지하는 특정 염기서열인 엔드로젠 반응요소(androgen response elements, $\mathrm{ARE}$ )에 결합하게 된다[30,37]. 이러한 엔드로젠 수용체의 활성화는 골격근 관련 전사인자들과의 상호 작용을 촉진시켜 근 비대 기전에 중요한 역할을 하는 유전자들의 발현을 증가시키는 것으로 보고되고 있다[24].

*Corresponding author Tel : +82-2-3277-2563, Fax : +82-2-3277-2846

E-mail : jun@ewha.ac.kr
엔드로젠 수용체의 스테로이드는 노인들이나, 장기간 침상 생활로 인해 근 부피가 소실된 환자들, 또는 알레르기, 염증 질환, 자가 면역질환의 면역 억제요법 등에 널리 이용 되어 왔으나 스테로이드의 이화작용(catabolism)에 의해 오히려 체중저하와 근 질량이 감소되는 근 위축을 유발시킨다고 보 고되었다[34]. 이와 같은 각종 동화작용 스테로이드 주입의 부작용에 대한 심각성 제기 연구 있으며, 스테로이드 치료 에 있어 다양한 성장인자들과 같은 대체 물질과 운동 중재 의 필요성이 제기되고 있다. 이에 관련하여 최근에는 엔드 로젠 수용체가 전립선 암 세포에서 리간드 비의존적 (ligand-independent)으로 epidermal growth factor (EGF), insulin-like growth factor-I (IGF-I), keratinocyte growth factor $(\mathrm{KGF})$ 등의 성장인자들에 의해 활성화 된다는 연구 가 보고된바 있고[7,10,16], 근육 세포인 $\mathrm{C} 2 \mathrm{C} 12$ 세포에서도 엔드로젠 물질 없이 IGF-I에 의해 엔드로젠 수용체가 리간 드 비의존적으로 활성화 되었다는 연구가 보고되었다[21].

엔드로젠 수용체가 리간드와 결합하여 근육 세포 내에서 활성화되고, 엔드로젠 수용체 목표 유전자들의 발현을 조절 하는 일련의 분자적 기작에 있어 중요한 역할을 하는 것이 엔드로젠 수용체 보조인자(coregulator)이며[28], 약 130여 개 이상의 coactivator 또는 corepressor로 구성되어있다. 그 중 coactivator는 엔드로젠 수용체 전사인자들의 전사 개시 
전(pre-initiation) 단계에서 리간드와 결합한 엔드로젠 수용 체 이합체(dimer)의 결합을 안정화(stabilization) 시키고 전 사 활성화를 촉진시키는 역할을 한다 $[18,23,24]$.

p160 coactivators는 steroid receptor cofactor family로도 불리며, 크기가 $160 \mathrm{kDa}$ 인 3가지 coactivator들을 일컫는데, steroid receptor coactivator 1 (SRC-1), glucocorticoid receptor interacting protein-1 (GRIP-1/TIF2/SRC-2), amplified in breast cancer-1 (AIB-1/SRC-3)으로 구성되어있다 [2,33]. SRC-1은 엔드로젠 수용체와의 결합을 통해 엔드로젠 수용체를 리간드 비의존적으로도 활성화 시킨다고 보고되 어있다[32]. GRIP-1 역시 엔드로젠 수용체의 전사 활성화에 필수적인 요소이며, 엔드로젠 수용체의 활성화와 상관없이 엔드로젠 수용체 비의존적(AR-independent)으로도 사람의 전립선 암 세포의 증식에 직접적으로 관여하는 것으로 알려 져 있다[18]. Androgen receptor associated protein 70 (ARA70)은 다른 coactivator에 비해 엔드로젠 수용체와 가 장 긴밀한 상호작용을 하는 유전자로 명확하게 밝혀져 있 어, 엔드로젠 수용체의 가장 특이적인 coactivator로 잘 알려 져 있다. 관련 선행 연구들에 따르면 dominant negative ARA70 또는 ARA70-specific siRNA가 전립선 암 세포의 증 식을 현저하게 억제시켰다는 결과를 제시하면서 ARA70가 엔드로젠 수용체의 활성화 기전에 매우 중요한 역할을 한다 고 보고하였다[15,29]. 이러한 coactivator들이 근육 세포 내 에서 엔드로젠 수용체 활성화와 엔드로젠 수용체 목표 유전 자들의 발현을 조절하는 분자적 기작에 있어 중요한 역할을 함에도 불구하고 관련 연구가 전립선 암세포를 중심으로 활 발히 이루어지고 있으나, 근육에서 이들의 분자적 기전에 대한 연구는 많이 부족한 실정이다.

IGF-I은 뇌하수체에서 분비되는 성장호르몬의 자극으로 간에서 생성된다[19,27]. 그러나 골격근에서도 국부적 (locally)으로 생산되어 자기 자신(autocrine)이나 주변 세포 들에(paracrine) 영향을 미치기도 한다[19]. 또한 IGF-I은 골 격근 세포의 증식을 돕고, 근단백질 합성을 증가시키며, 근 단백질의 분해를 막아주는 역할을 하여 근 비대에 필수적인 요소로 알려져 있다[6,8,11,14,17,22,25]. Mitogen activated protein kinase (MAPK)는 IGF-I에 의해 활성화되는 주요 하 부 신호전달 경로이자 근 비대 관련 신호전달 체계에 있어 중요한 경로로 잘 알려져 있으며 $[4,5,12,20,26], \mathrm{MAPK}$ 중 p38 MAPK와 extracellular regulated kinase 1 and 2 (ERK1/2)는 PI3K/Akt 경로와 함께 주요 IGF-I 하부 신호 전달 경로로 잘 알려져 있다. IGF-I이 근비대를 유도하는데 있어 ERK1/2 경로가 활성화되며[12], 과부하로 유도된 근비 대에 있어서도 $\mathrm{p} 38 \mathrm{MAPK}$ 의 활성이 증가하였다고 보고되 어 있다[5].

이와 같이 많은 선행 연구들에서 엔드로젠 수용체와
IGF-I은 근부피 유지 및 증대에 있어 필수적인 요소로 언 급 되어 왔고, 이들 각각이 근육에 미치는 영향 및 신호전 달 경로에 대한 연구는 매우 활발히 이루어져 왔다. 그러 나 최근 엔드로젠 수용체의 리간드인 스테로이드 물질들에 대한 문제점과 대체 물질에 관한 필요성이 언급되고 있고, 그에 따라 IGF-I 등과 같은 다양한 성장인자들에 의한 엔 드로젠 수용체의 리간드 비의존적 활성화에 대한 가능성 및 연구 결과들이 제시되고 있다. 따라서 엔드로젠 수용체 활성화의 보조 역할을 하는 엔드로젠 수용체 coactivator에 있어서도 비리간드에 의한 활성에 관한 연구가 필요하다고 사료된다.

따라서 본 연구에서는 $\mathrm{C} 2 \mathrm{C} 12$ 근육 세포에서 IGF-I이 리 간드 비의존적으로 엔드로젠 수용체 coactivator 유전자 발 현에 영향을 미치는지를 알아보고자 하였다. 비록 p38 MAPK, ERK1/2 신호전달 경로가 IGF-I의 중요 하부신호 전달 경로임은 매우 잘 알려져 있지만, 근육 세포에서 엔드 로젠 수용체 coactivator의 발현에 있어 이들 경로의 역할에 관한 연구는 전무한 실정이기 때문에 위 신호전달 경로를 차단하는 SB203580과 PD98059 억제제를 각각 IGF-I과 함께 처리시켜봄으로써 엔드로젠 수용체 coactivator 유전자 발현 에 있어 p38 MAPK, ERK1/2 경로의 역할도 확인해 보고자 하였다.

\section{재료 및 방법}

\section{세포 배양 및 시약 처리}

C2C12 세포는 10\% fetal bovine serum (FBS) (Hyclone, Logan, UT), $100 \mathrm{U} / \mathrm{ml}$ 의 penicillin $\mathrm{G}, 100 \mu \mathrm{g} / \mathrm{ml}$ 의 streptomycin sulfate (Welgene, KOREA)를 함유하고 있는 Dulbecco's modified Eagle's medium (DMEM) (Welgene, $\mathrm{KOREA})$ 을 이용하여 $37^{\circ} \mathrm{C}, 5 \% \mathrm{CO}_{2}$ 의 환경에서 배양하였 다. 세포는 6-well plate에 $2 \mathrm{ml}$ 당 $5 \times 10^{5}$ 세포를 분주하고 48 시간 후 $2 \%$ horse serum (HS) (Hyclone, Logan, UT)이 함유된 분화배지에 분화를 유도하면서 $250 \mathrm{ng} / \mathrm{ml}$ 의 IGF-I (Sigma Aldrich, St. Louis, MO)을 처리하거나 $250 \mathrm{ng} / \mathrm{ml}$ 의 IGF-I을 p38 MAPK 억제제인 $10 \mu \mathrm{M}$ 의 SB203580, 또는 $\mathrm{ERK} 1 / 2$ 억제제인 $30 \mu \mathrm{M}$ 의 PD98059와 함께 5 분 또는 30 분간 처리하였다. SB203580과 PD98059는 Sigma Aldrich사 로부터 구입하였다.

\section{Western blot}

단백질을 추출하기 위하여 cell lysis buffer $(50 \mathrm{mM}$ Tris, pH 7.5, $150 \mathrm{mM} \mathrm{NaCl}, 1 \%$ Triton X-100, 1 mM PMSF, and complete protease inhibitor cocktail)를 처리한 후 scraper 를 이용해 세포를 긁어낸 후 $4^{\circ} \mathrm{C}$ 에서 $13,000 \mathrm{rpm}$ 으로 15 분 
간 원심분리 하였다. 분리된 단백질을 얻어낸 뒤 Bradford protein assay kit (Bio-Rad, Hercules, CA)를 사용하여 단백 질 농도를 측정하였다. $60 \mu \mathrm{g}$ 의 단백질을 $8 \% \mathrm{SDS}-\mathrm{PAGE}$ gel에서 $150 \mathrm{~V}$ 로 1 시간 동안 전기 영동 한 뒤, PVDF membrane으로 transfer 하였다 $(12 \mathrm{~V}, 1 \mathrm{hr})$. 또한 Ponceau $\mathrm{S}$ 로 모든 lane의 동량의 단백질을 확인한 후 각각의 membrane 을 5\% skim milk로 1 시간 blocking 한 뒤 0.1\% TBST로 5 분씩 3번 씻어내었다. 다음으로 GRIP-1 (polyclonal rabbit antibody, 1:1,000), SRC-1 (monoclonal mouse antibody, 1:1,000), ARA70 (polyclonal rabbit antibody, 1:2,000) (Santa Cruz Biotechnology, Santa Cruz, CA), 그리고 a -tubulin (monoclonal mouse antibody, 1:2,500) (Calbiochem, Gibbstown, NJ) 1차 항체를 5\% bovine serum albumin (BSA)에 희석하여 $4^{\circ} \mathrm{C}$ 에서 12 시간 반응시켰다. 그 후, $0.1 \% \mathrm{TBST}$ 로 5 분씩 3번 씻어낸 뒤 2차 항체(anti-rabbit or mouse IgG horse-radish peroxidase-linked secondary antibody, 1:5,000) (Cell signaling, Beverley, MA)를 상온에서 1 시간 동안 반응시켰다. 반응이 끝난 후 위와 동일한 방법으 로 씻어낸 뒤, enhanced chemiluminescent (ECL) (GE Healthcare UK Ltd., Little Chalfont, UK) 용액을 1:1 비율 로 섞어 1 분 동안 반응 시킨 뒤 LAS-3000 imaging system (Fuji Film, Tokyo, Japan)으로 단백질 발현을 확인하였다. 모든 coactivator들의 단백질 발현양은 각각의 a-tubulin의 단백질 양으로 보정하여 densitometry (Scion image)를 이 용하여 수치화 하였다.

\section{$\mathrm{RNA}$ 추출 및 $\mathrm{CDNA}$ 합성}

RNA를 추출하기 위하여 TRIzol 용액(Invitrogen Life Technologies, Carlsbad, CA)을 이용한 phenol-chloroform 추출 기법을 사용하였다. TRIzol 용액을 well당 각각 $1 \mathrm{ml}$ 씩 넣고, $200 \mu \mathrm{l}$ 의 chloroform을 처리하여 잘 섞어준 뒤 $4^{\circ} \mathrm{C}, 13,000 \mathrm{rpm}$ 에서 15 분 동안 원심분리를 하였다. 상층액 을 분리하여 isoprophanol과 $1: 1$ 비율로 섞어준 뒤, $4^{\circ} \mathrm{C}$, $12,000 \mathrm{rpm}$ 에서 10 분간 원심분리를 하였다. 생성된 pellet을 $\mathrm{DEPC}$ 로 희석한 $75 \% \mathrm{ETOH}$ 에 씻어내고, $4^{\circ} \mathrm{C}, 12,000 \mathrm{rpm}$ 에 서 5 분간 원심분리를 하였다. 최종 추출된 pellet을 상온에 서 10 분간 말린 뒤 ultra pure water $60 \mu 1$ 에 녹인 후, $\mathrm{UV}$ 흡광도 $260 \mathrm{~nm}$ 에서 농도를 측정하였다. cDNA를 합성하기
위해 $1 \mu \mathrm{g} / \mu \mathrm{l}$ 의 RNA를 $5 \times$ buffer $4 \mu \mathrm{l}$, random primer $2 \mu \mathrm{l}$, $2.5 \mathrm{mM}$ dNTP $2 \mu \mathrm{l}$, Rnase inhibitor $0.5 \mu \mathrm{l}$, 그리고 reverse transcriptase $0.25 \mu \mathrm{l}$ (Invitrogen Life Technologies, Carlsbad, CA)와 혼합하여 $25^{\circ} \mathrm{C} 10$ 분, $42^{\circ} \mathrm{C} 60$ 분, 그리고 $95^{\circ} \mathrm{C} 5$ 분간 $\mathrm{PCR}$ 을 이용해 $\mathrm{CDNA}$ 를 합성하였다.

\section{Real-time quantitative PCR}

GRIP-1과 SRC-1, 그리고 ARA70 messenger RNA (mRNA) 발현을 측정하기 위하여 double-stranded DNA dye인 SYBR Green PCR master mix (Finnzyme, Espoo, Finland)를 이용하여 real-time PCR을 실시하였다. 실험에 사용한 primer sequence는 Table 1에 제시하였으며, 모든 Primer는 코스모사(Cosmo Genetech, KOREA)에서 제작 및 구입하여 사용하였다. 모든 real-time $\mathrm{PCR}$ 분석은 $\mathrm{ABI}$ PRISM 7700 system (Applied Biosystems Inc., Foster City, $\mathrm{CA}$ )을 이용하였으며, 모든 샘플은 3 회 반복 실험하여 합성 시킨 $\mathrm{cDNA}$ 를 각각 2 회 이상 반복 측정하였다. $95^{\circ} \mathrm{C} 15$ 초, $60^{\circ} \mathrm{C} 1$ 분간 40 cycle 을 측정하여 $\mathrm{CT}$ 값을 구하고, 융해 곡 선 확인을 위해 40 cycle 이후 dissociation stage를 추가하여 $95^{\circ} \mathrm{C} 15$ 초, $60^{\circ} \mathrm{C} 1$ 분의 조건을 2 번 반복하여 현광 signal의 크기를 측정하였다. 반응이 완료된 후 증폭곡선의 S 커브가 급격히 올라가는 지점과 $\mathrm{CT}$ 값이 추출된 지점이 일치하였 음을 확인하고, 융해 곡선 그래프에서 단일 산물이 증폭 되 었음을 확인한 뒤 최종적으로 $\mathrm{CT}$ 값을 데이터로 처리 하였 다. 결과는 상대 정량법인 단순 $\mathrm{CT}$ 값 비교 분석 방법을 사 용하였다. 따라서 target mRNA 발현양은 house keeping gene으로 많이 사용되고 있는 glyceraldehyde 3-phosphate dehydrogenase $(\mathrm{GAPDH})$ 의 $\mathrm{CT}$ 값으로 상대 정량 하여 보 정하였다.

\section{자료처리}

IGF-I 처리와 p38 MAPK 억제제인 SB203580, ERK1/2 억 제제인 PD98059 처리에 따른 $\mathrm{C} 2 \mathrm{C} 12$ 세포에서의 엔드로젠 수용체 coactivator 유전자들의 단백질 발현과 mRNA 발현 의 유의성 검증을 위하여 SPSS 12.0 for window를 이용하 여 일원배치분산분석(one-way ANOVA)을 실시하였으며, 집단 간에 유의한 차이가 있는지를 검증하기 위하여 Tukey's 사후검정을 실시하였다 $(p<0.05)$.

Table 1. Primer sequences for real-time PCR

\begin{tabular}{lll}
\hline Gene & Forward primers & Reverse primers \\
\hline ARA70 & CAAGCCTGACTCCTGTACCAACTG & GGCTTCCTTCTCACAGTTGTCATC \\
GRIP-1 & AGAACCAGCCAAACCAAC & TGGTTGAGGATTTCCCTCTG \\
SRC-1 & GCTCCAGCAAACTCCACCTACTT & AATGTTTGCGTTTCCACCTG \\
GAPDH & ATGACAATGAATACGGCTACAGCAA & GCAGCGAACTTTATTGATGGTATT \\
\hline
\end{tabular}




\section{결 과}

\section{단백질 발현}

IGF-I이 엔드로젠 수용체 coactivator 유전자의 단백질 발 현에 미치는 영향을 알아보기 위하여 $\mathrm{C} 2 \mathrm{C} 12$ 세포에 분화를 유도하면서 IGF-I을 처리하고, IGF-I에 의한 엔드로젠 수용 체 coactivator 단백질 발현의 변화에 있어 $\mathrm{p} 38 \mathrm{MAPK}$ 와 ERK1/2의 역할을 알아보기 위해 IGF-I 과 SB203580, 또는 PD98059를 각각 함께 처리하여 western blot을 실시하였다. 그 결과 Fig. 1에 제시된 바와 같이 통제군과 비교하였을 때 GRIP-1의 단백질 발현이 IGF-I에 의해 $45 \%$ 증가하였다. 그 러나 p38 MAPK와 ERK1/2 경로 억제제인 SB203580과 PD98059를 각각 IGF-I과 함께 처리한 결과 IGF-I에 의한 GRIP-1 단백질 발현의 증가가 현저히 감소되었다. 엔드로젠 수용체의 또 다른 coactivator 중 하나인 SRC-1의 단백질 발 현을 알아본 결과 IGF-I을 처리하였을 때 SRC-1의 단백질 발현은 통제군에 비해 $45 \%$ 증가하였다. 반면에 SB203580 과 PD98059 를 각각 IGF-I과 함께 처리한 결과 IGF-I만을 처리한 그룹에 비해 단백질 발현이 현저하게 감소되었다 (Fig. 2). Fig. 3에 제시된 바와 같이 $\mathrm{C} 2 \mathrm{C} 12$ 세포에 IGF-I을 처리하자 엔드로젠 수용체의 가장 특이적인 coactivator로 알려진 ARA70의 단백질 발현은 통제군과 비교하였을 때 $85 \%$ 유의하게 증가하였다. 그러나 SB203580과 PD98059를

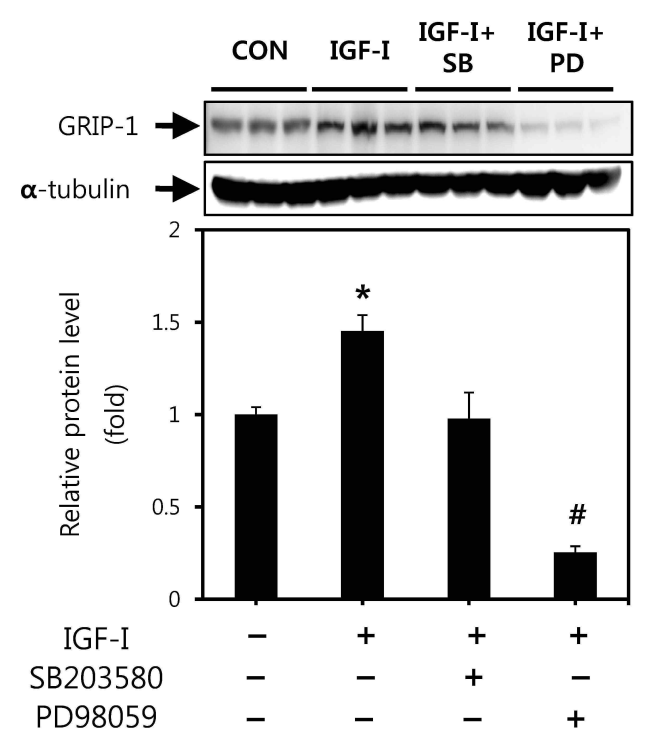

Fig. 1. GRIP-1 expression in C2C12 cells treated with IGF-I $(250 \mathrm{ng} / \mathrm{ml}$ ) for $30 \mathrm{~min}$ in the absence or presence of $10 \mu \mathrm{M}$ SB203580 or $30 \mu \mathrm{M}$ PD98059. Sixty micrograms of total protein were resolved on $8 \%$ SDS-PAGE gel, followed by immunoblot with GRIP-1 and $\alpha$-tubulin antibodies. Inset. Western blot image of GRIP-1 and a -tubulin detection. Values are means \pm SE with $n=3$ for each condition. ${ }^{*} p<0.05$ vs. control. $\# p<0.05$ vs. IGF-I.

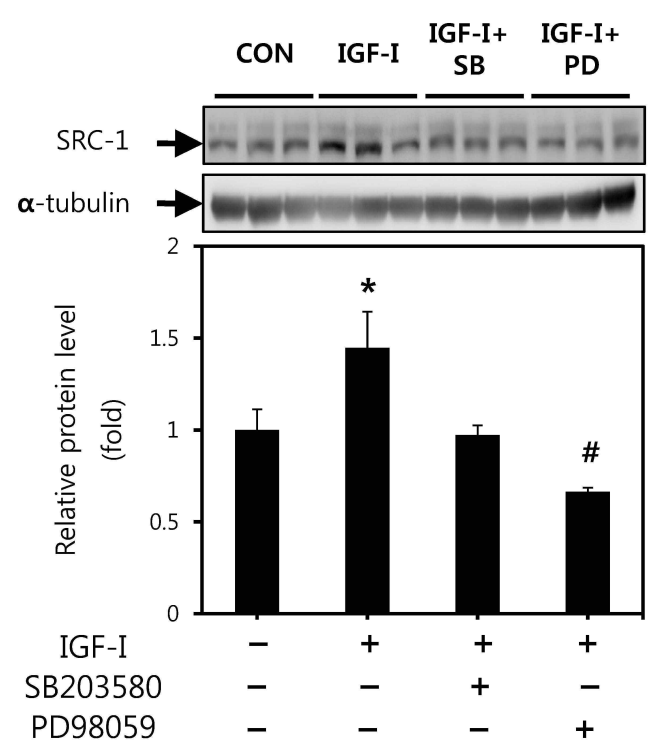

Fig. 2. Effect of treatment with $250 \mathrm{ng} / \mathrm{ml}$ IGF-I for $30 \mathrm{~min}$ in the absence or presence of $10 \mu \mathrm{M}$ SB203580 or $30 \mu$ M PD98059 on the SRC-1 protein level in C2C12 cells. Sixty micrograms of protein were fractionated by $8 \%$ SDS-PAGE, followed by immunoblot with SRC-1 and $\alpha$-tubulin antibodies. Inset. Images of Western blot analysis conducted using SRC-1 and a-tubulin detection. Values are means \pm SE with $n=3$ for each condition. ${ }^{*} p<0.05$ vs. control. \# $p<0.05$ vs. IGF-I.

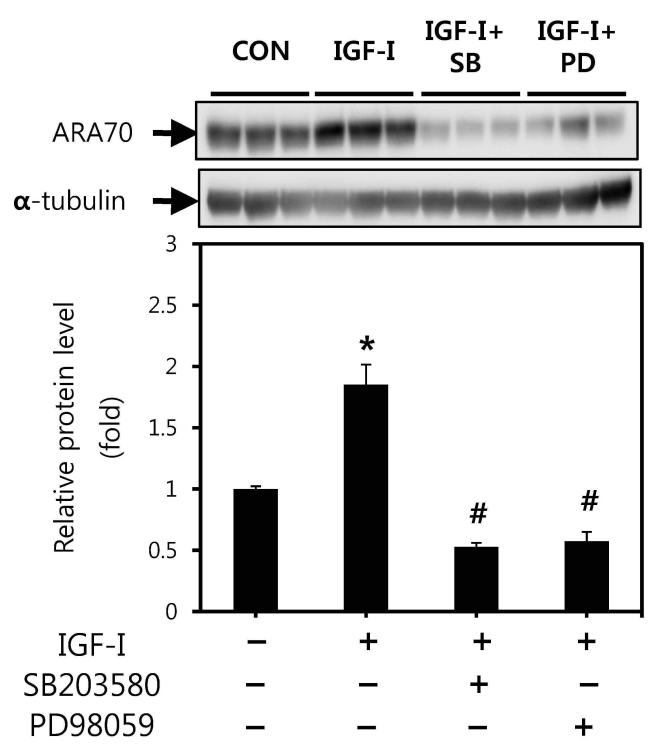

Fig. 3. ARA70 expression in $\mathrm{C} 2 \mathrm{C} 12$ cells treated with IGF-I ( $250 \mathrm{ng} / \mathrm{ml}$ ) for $30 \mathrm{~min}$ in the absence or presence of SB203580 $(10 \mu \mathrm{M})$ or PD98059 $(30 \mu \mathrm{M})$. Cell lysates were fractionated by $8 \%$ SDS-PAGE, followed by immunoblot with ARA70 and a-tubulin antibodies. Inset. Western blot image of ARA70 and a-tubulin detection. Values are means \pm SE with $n=3$ for each condition. ${ }^{*} p<0.05$ vs. control. \# $\#<0.05$ vs. IGF-I. 
각각 IGF-I과 함께 처리하자 IGF-I에 의해 발현이 증가된 ARA70 단백질 발현이 현저히 감소되었다.

\section{mRNA 발현}

IGF-I이 엔드로젠 수용체 coactivator mRNA 발현에 어떠 한 영향을 미치는지 알아보기 위해 $\mathrm{C} 2 \mathrm{C} 12$ 세포에 분화를 유도하면서 $250 \mathrm{ng} / \mathrm{ml}$ 의 IGF-I을 5 분간 처리하였다. 또한 IGF-I에 의한 coactivator mRNA 발현의 변화에 있어 IGF-I 의 하부신호전달 경로 중 하나인 p38 MAPK와 ERK $1 / 2$ 신 호전달 경로의 역할을 알아보기 위해 IGF-I 을 SB203580, 또 는 PD98059 와 함께 각각 5 분간 처리하여 real-time PCR 분석을 실시하였다. Fig. 4에 제시된 바와 같이 IGF-I을 처리 한 세포에서는 통제군과 비교하였을 때 GRIP-1의 mRNA 발현이 $64 \%$ 유의하게 증가 하였다. 그러나 SB203580과 PD98059를 각각 IGF-I과 함께 처리하였을 때에는 IGF-I만을 처리한 그룹에 비해 GRIP-1 mRNA 발현이 감소하는 경향 을 보였으나 유의한 차이를 보이지는 않았다. Fig. 5에 제시 된 바와 같이 IGF-I을 처리하자 SRC-1의 mRNA 발현은 통 제군에 비해 $36 \%$ 유의하게 증가하였다. 반면에, SB203580과 PD98059를 각각 IGF-I과 함께 처리한 결과 IGF-I에 의해 발 현이 증가된 SRC-1의 mRNA 발현을 감소시켰으나 유의한 차이를 보이지 않았다. IGF-I에 의한 ARA70 mRNA 발현의 변화를 살펴보기 위해 $\mathrm{C} 2 \mathrm{C} 12$ 세포에 IGF-I을 처리한 결과 통제군에 비해 발현이 $50 \%$ 유의하게 증가하였다. 그러나 SB203580, PD98059를 각각 IGF-I과 함께 처리한 결과 IGF-I 만을 처리하였을 때 유도된 ARA70 mRNA 발현 증가 수준 이 감소하는 경향을 보였으나 유의한 차이는 볼 수 없었다.

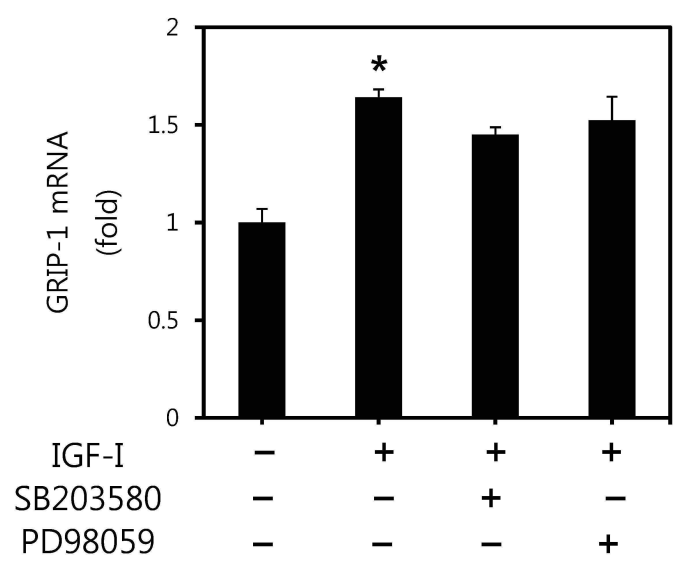

Fig. 4. Real-time PCR analysis of GRIP-1 mRNA after treatment with $250 \mathrm{ng} / \mathrm{ml}$ IGF-I for $5 \mathrm{~min}$ in the absence or presence of $10 \mu \mathrm{M}$ SB 203580 or $30 \mu \mathrm{M}$ PD98059. Target mRNA values are shown normalized to the GAPDH mRNA level for each sample. Samples were analyzed in duplicate in parallel with GAPDH. Values are means \pm SE with $\mathrm{n}=3$ for each condition. * $p<0.05$ vs. control.

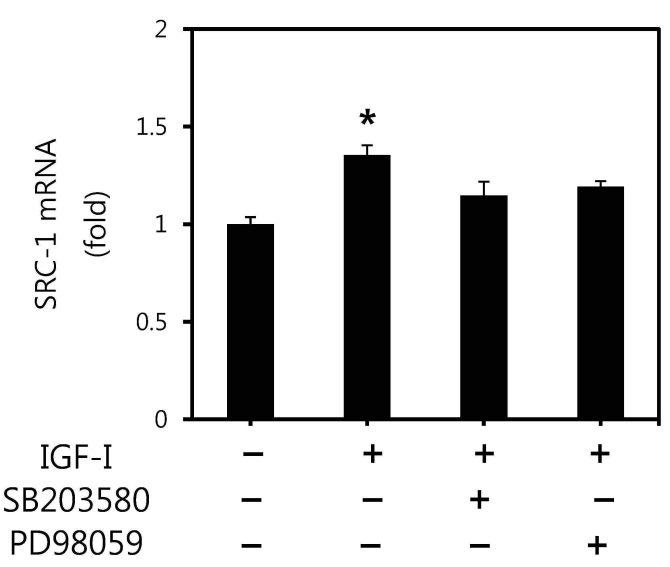

Fig. 5. Real-time PCR analysis of SRC-1 mRNA after treatment with $250 \mathrm{ng} / \mathrm{ml}$ IGF-I for $5 \mathrm{~min}$ in the absence or presence of $10 \mu \mathrm{M}$ SB 203580 or $30 \mu \mathrm{M}$ PD98059 in C2C12. Target mRNA values are shown normalized to the GAPDH mRNA level for each sample. Samples were analyzed in duplicate in parallel with GAPDH. Values are means $\pm S E$ of three independent experiments. Values are means $\pm S E$ with $n=3$ for each condition. ${ }^{*} p<0.05$ vs. control.

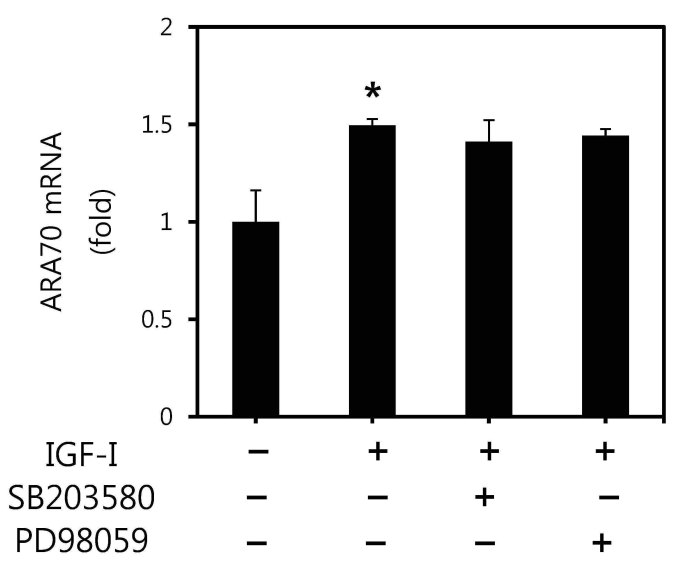

Fig. 6. Real-time PCR analysis of ARA70 mRNA after treatment with $250 \mathrm{ng} / \mathrm{ml}$ IGF-I for $5 \mathrm{~min}$ in the absence or presence of $10 \mu \mathrm{M}$ SB 203580 or $30 \mu \mathrm{M}$ PD98059. Target mRNA values are shown normalized to the GAPDH mRNA level for each sample. Samples were analyzed in duplicate in parallel with GAPDH. Values are means $\pm \mathrm{SE}$ of three independent experiments. Values are means $\pm \mathrm{SE}$ with $\mathrm{n}=3$ for each condition. ${ }^{*} p<0.05$ vs. control.

\section{고 찰}

IGF-I과 엔드로젠 수용체는 근 비대 기전에 있어 매우 중 요한 역할을 하는 것으로 잘 알려져 있으며, 엔드로젠 수용 체 coactivator는 엔드로젠 수용체 활성화 및 발현에 중요한 
보조자 역할을 한다[18]. 최근 보고되고 있는 스테로이드 물 질들의 각종 부작용에 관한 연구들은 엔드로젠 수용체의 비 리간드 물질에 대한 연구의 필요성을 제기하였으며, 본 연 구에서 사용한 IGF-I이 EGF, KGF 등의 성장인자들과 함께 전립선 암 세포에서 엔드로젠 수용체를 리간드 비의존적으 로 활성화 시킬 수 있다는 가능성이 제시된 바 있다 $[7,10,16]$. 또한 최근에는 근육 세포인 $\mathrm{C} 2 \mathrm{C} 12$ 세포에서도 엔 드로젠 물질 없이 IGF-I에 의해 엔드로젠 수용체가 활성화 되었다는 연구가 보고되었다[21]. 이러한 선행 연구들을 바 탕으로 본 연구에서는 IGF-I이 리간드 비 의존적으로 엔드 로젠 수용체 활성화 단계에서의 안정화 및 발현 조절에 중 요한 보조자 역할을 하는 엔드로젠 수용체 coactivator 발현 에 어떠한 영향을 미치는지에 대해 알아보았으며, 이 과정 에서 IGF-I의 하부신호전달 경로인 p38 MAPK, ERK1/2의 역할도 알아보았다.

\section{IGF-1에 의한 AR coactivator 유전자 발현}

본 연구에서 첫 번째로 확인할 수 있었던 중요한 사실은 IGF-I을 처리하였을 때 엔드로젠 수용체 coactivator들의 단 백질과 $\mathrm{mRNA}$ 의 발현이 리간드 비의존적 으로도 증가하였 다는 사실이다. 본래 엔드로젠 수용체 coactivator들은 엔드 로젠 수용체와 마찬가지로 자신의 리간드인 엔드로젠에 의 해 활성화 되고 발현이 증가한다[35]. GRIP-1은 엔드로젠에 의해 발현이 증가하는데, $\mathrm{C} 2 \mathrm{C} 12$ 골격근 세포에 엔드로젠 물질 중 하나인 테스터스테론을 처리하자 GRIP-1의 mRNA의 발현이 유의하게 증가하였다고 보고된 바 있다 [9]. 또한 SRC-1은 엔드로젠 수용체의 전사 활성화 (transcriptional activity)에 매우 중요한 요소로 잘 알려져 있으며, ARA70는 아주 낮은 농도의 엔드로젠 처리에 의해 서도 발현이 증가하며, 엔드로젠 수용체 목표 유전자들의 발현을 촉진시킨다[38]. Siriett 등[31]은 골격근 증식을 억제 시키는 유전자인 myostatin의 발현을 억제시키자 ARA70의 발현이 증가하였음을 보고하였는데, 이는 myostatin의 발현 이 억제되어 근육의 증식이 활발하게 일어나는 과정에서 ARA70가 발현되어 엔드로젠 수용체의 발현에 영향을 미쳤 다고 생각해 볼 수 있다. 이와 같이, 엔드로젠 수용체의 기 능 및 세포 증식, 발달과 엔드로젠 물질에 의한 엔드로젠 수용체 coactivator들의 역할 규명에 대한 연구는 이루어졌 지만, 비리간드 물질인 IGF-I과 같은 성장인자들에 의한 근 육세포에서의 엔드로젠 수용체 coactivator 유전자 발현 변 화에 대한 연구는 이루어지지 않았다. 따라서 본 연구에서 엔드로젠 수용체 활성화 기전에 중요한 역할을 하는 coactivator들이 골격근 세포에서 리간드 비의존적으로 IGF-I 에 의해 발현이 증가되었다는 결과를 제시하였다는 점에 의의가 있다고 생각된다.
IGF-| 하부신호 전달 경로가 IGF-|에 의한 AR coactivator 유전자 발현에 미치는 영향

두 번째로 본 연구를 통해 확인한 사실은 p38 MAPK 와 ERK $1 / 2$ 억제제를 IGF-I과 함께 처리하였을 때는 IGF-I에 의해 유도된 엔드로젠 수용체 coactivator들의 단백질 및 $\mathrm{mRNA}$ 발현이 억제되었다는 것이다. p38 MAPK와 ERK $1 / 2$ 는 IGF-I에 의해 활성화되는 IGF-I의 주요 하부 신 호전달 경로이며 근 비대에 관련된 신호전달 체계와 골격근 관련 유전자의 발현을 조절하는데 있어 매우 중요한 경로로 잘 알려져 있다[4,26]. 앞선 연구 결과들을 살펴보면 $\mathrm{p} 38$ MAPK 억제제인 SB203580을 근육세포에 처리하자 근육세 포의 증식이 현저히 억제되고 세포주기 조절인자인 p21을 비롯한 myogenic regulatory factors (MRFs), myogenin, 그 리고 myosin heavy chain 등 골격근 관련 유전자들의 발현 이 거의 이루어지지 않았다고 보고하였다[36,39]. 또한 Hao 등[13]에 따르면 ERK1/2의 억제제인 PD98059를 C2C12 myotube에 처리하자 myotube의 직경이 감소하고, Akt와 $\mathrm{GSK} 3 \mathrm{a} / \beta$ 의 단백질 인산화가 현저히 억제되었다고 보고하 였다. 이와 같은 선행 연구들에서 IGF-I의 하부신호전달 경 로인 $\mathrm{p} 38 \mathrm{MAPK}$ 와 ERK $1 / 2$ 경로가 근육세포의 증식 및 분 화에 미치는 영향을 고찰한 것과는 달리, 본 연구에서는 p38 MAPK, ERK1/2 경로를 차단해봄으로써 IGF-I이 리간 드 비의존적으로 엔드로젠 수용체 coactivator 유전자 발현 을 증가 시킴에 있어 위 경로가 필수적임을 확인하였다. 그 러나 위 결과들에서 볼 수 있듯이 IGF-I에 의한 coactivator 의 발현에 있어 p38 MAPK, ERK1/2 억제제를 각각 처리하 였을 때 coactivator 단백질의 발현은 현저히 억제 되었음에 도 불구하고 mRNA 수준에 있어서는 약간의 발현이 감소되 었을 뿐 단백질 수준만큼 현저하게 발현이 억제되는 결과는 볼 수 없었다. 이는 실험을 실시함에 있어 mRNA 발현 측 정은 IGF-I과 억제제들의 처리시간을 5 분으로, 단백질 발현 측정은 IGF-I과 억제제들의 처리시간을 30 분으로 설정한 실험 조건의 차이를 생각해 볼 수도 있으며, 다른 한편으로 는 일반적인 실험 상황에 있어 전사 수준과 단백질 발현 수 준의 정도가 일치하지 않는 경우, 혹은 정반대 경향의 결과 가 나타나는 많은 경우들을 고려하여 해석해밨을 때 IGF-I 에 의한 coactivator 단백질 발현 증가는 단백질의 안정화 (stability) 및 번역의 능력(capacity) 및 효율성(efficiency) 증 대와 같은 전사 후(post-transcription) 단계에서 유전자의 발 현이 조절되었을 것으로 사료된다.

\section{IGF-|과 엔드로젠 수용체 coactivator의 향후 연구 방향}

결론적으로, 본 연구에서는 $\mathrm{C} 2 \mathrm{C} 12$ 골격근 세포에서 IGF-I이 리간드 비의존적으로 엔드로젠 수용체 coactivator 인 GRIP-1, SRC-1, ARA70의 유전자 발현에 유의한 영향을 
미쳤다는 사실을 확인하였다. 또한 IGF-I이 이들 coactivator 의 발현을 증가시킴에 있어서 $\mathrm{p} 38 \mathrm{MAPK}, \mathrm{ERK} 1 / 2$ 신호전 달 경로가 중요한 역할을 한다는 사실도 확인하였다. 비록 IGF-I의 하부 신호전달 경로로 p38 MAPK와 ERK $1 / 2$ 경로 는 매우 잘 알려져 있지만 근육 세포 내에서 IGF-I과 엔드로 젠 수용체 coactivator와 관련하여 위 신호전달 경로에 연관 된 연구는 아직 부족한 것이 사실이다. 본 연구에서 제시한 결과들이 골격근에서 엔드로젠 물질들이 없이도 IGF-I에 의 해 엔드로젠 수용체 coactivator 발현에 영향을 미쳤다는 것 을 보여주었기 때문에 근비대 기전에 있어 성장인자, 운동 중재의 필요성 증명을 위한 중요한 단서가 될 것이라 생각 되지만, 이와 관련한 다른 수 많은 coactivator들에 관한 연 구가 더 진행되어야 할 것이다. 또한 이를 바탕으로 IGF-I에 의한 엔드로젠 수용체 corepressor들의 유전자 발현 억제와 신호전달 억제 등의 기능을 규명할 수 있다면, 근육에서 IGF-I과 엔드로젠 수용체 유전자 간의 분자적 기전을 보다 자세하게 설명할 수 있는 계기가 될 수 있을 것이라 생각된 다. 더 나아가, 이러한 향후 관련 연구들에 있어 IGF-I의 하 부 신호 전달 경로인 $\mathrm{p} 38 \mathrm{MAPK}$ 와 ERK1/2를 비롯한 다른 신호전달 경로들과 상, 하부 신호전달 경로에 관한 연구도 함께 수행되어야 할 것이다.

\section{감사의 글}

이 논문은 2009년도 부산대학교 박사후연수과정지원사업 에 의하여 연구되었음.

\section{References}

1. Antonio, J., J. D, Wilson, and F. W. George. 1999. Effects of castration and androgen treatment on androgen-receptor levels in rat skeletal muscles. J. Appl. Physiol. 87, 2016-2029.

2. Anzick, S. L., J. Kononen, R. L. Walker, D. O. Azorsa, M. M. Tanner, X. Y. Guan, G. Sauter, O. P. Kallioniemi, J. M. Trent, and P. S. Meltzer. 1997. AIB1, a steroid receptor coactivator amplified in breast and ovarian cancer. Science 277, 965-968.

3. Bhasin, S., L. Woodhouse, and T. W. Storer. 2003. Androgen effects on body composition. Growth Horm IGF Res. 13, S63-S71.

4. Butler, A. A., S. Yakar, I. H. Gewolb, M. Karas, Y. Okubo, and D. LeRoith. 1998. Insulin-like growth factor-I receptor signal transduction: at the interface between physiology and cell biology. Comp. Biochem Mol. Biol. 121, 19-26.

5. Carlson, C. J., Z. Fan, S. E. Gordon, and F. W. Booth. 2001. Time course of the MAPK and PI3-kinase response within $24 \mathrm{~h}$ of skeletal muscle overload. J. Appl. Physiol. 91, 2079-2087.

6. Coleman, M. E., F. DeMayo, K. C. Yin, H. M. Lee, R. Geske, C. Montgomery, and R. J. Schwartz. 1995. Myogenic vector expression of insulin-like growth factor I stimulates muscle cell differentiation and myofiber hypertrophy in transgenic mice. J. Biol. Chem 270, 12109-12116.

7. Culig, Z., A. Hobisch, M. V. Cronauer, C. Radmayr, J. Trapman, A. Hittmair, G. Bartsch, and H. Klocker. 1994. Androgen receptor activation in prostatic tumor cell lines by insulin-like growth factor-I, keratinocyte growth factor, and epidermal growth factor. Cancer Res. 54, 5474-5478.

8. Florini, J. R., D. Z. Ewton, and S. A. Coolican. 1996. Growth hormone and the insulin-like growth factor system in myogenesis. Endocr. Rev. 16, 481-517.

9. Francesca, W., C. Massimillino, G. Lucia, F. Andrea, B. Sergio, and M. Costanzo. 2008. Androgen receptor expression during $\mathrm{C}_{2} \mathrm{C} 12$ skeletal muscle cell line differentiation. Mol. Cell Endocrinol. 292, 11-19.

10. Francesco, O. Jr., T. Beatrice, G. Virginie, L. Serge, A. Christophe, S. Christian, and S. Charles. 2002. Potential action of IGF-I and EGF on androgen receptor nuclear transfer and transactivation in normal and cancer human prostate cell lines. Mol. Cell Endocrinol. 198, 105-114.

11. Galvin, C. D., O. Hardiman, and C. M. Nolan. 2003. IGF-I receptor mediates differentiation of primary cultures of mouse skeletal myoblasts. Mol. Cell Endocrinol. 200, 19-29.

12. Haddad, F and G. R. Adams. 2004. Inhibition of MAP/ERK kinase prevents IGF-I-induced hypertrophy in rat muscles. J. Appl. Physiol. 96, 203-210.

13. Hao, S., M. S. Jason, W. Caiyun, M. P. Jonatha, M. H. Kevin, L. G. Alan, and E. G. David. 2009. Mitogen-activated protein kinase signaling is necessary for the maintenance of skeletal muscle mass. Am J. Physiol. 296, C1040-1048.

14. Hill, M. and G. Goldspink. 2003. Expression and splicing of the insulin-like growth factor gene in rodent muscle is associated with muscle satellite (stem) cell activation following local tissue damage. J. Physiol. 549, 409-418.

15. Hu, Y. C., S. Yeh, S. D. Yeh, R. S. Erick, J. Huang, P. Li, C. L. Hsu, H. J. Ting, H. K. Lin, L. Wang, E. Kim, J. Ni, and C. Chang. 2004. Functional domain and motif analyses of androgen receptor coregulator ARA70 and its differential expression in prostate cancer. J. Biol. Chem 279, 33438-33446.

16. Jennifer, D. W., H. Kathy, W. Libby, N. Peter, C. Ilsa, and R. P. Stephen. 2006. Interaction of IGF Signaling and the androgen receptor in prostate cancer progression. $J$. Cell Biochem 99, 392-401.

17. Jennische, E. and H. A. Hansson. 1987. Regenerating skeletal muscle cells express insulin-like growth factor I. Acta 
Physiol. Scand 130, 327-332.

18. Joanne, E. and M. S. John. 2005. The androgen receptor and signal-transduction pathways in hormone-refractory prostate cancer. Part 2: androgen receptor cofactors and bypass pathways. BJU Int. 95, 1327-1335.

19. Jones, J. I. and D. R. Clemmons. 1995. Insulin-like growth factors and their binding proteins: biological action. Endocr. Rev. 16, 3-34.

20. Keren, A., Y. Tamir, and E. Bengal. 2006. The p38 MAPK signaling pathway: A major regulator of skeletal muscle development. Mol. Cell Endocrinol. 252, 224-230.

21. Kim, H. J. and W. J. Lee. 2009. Insulin-like growth factor-I induces androgen receptor activation in differentiating $\mathrm{C} 2 \mathrm{C} 12$ skeletal muscle cells. Mol. Cells 28, 189-194.

22. Lewis, M. I., G. D. Horritz, D. R. Clemmons, and M. Fournier. 2002. Role of IGF-I and IGF-binding proteins within diaphragm muscle in modulating the effects of nandrolone. Am J. Physiol. 282, E483-490.

23. Mangelsdorf, D. J., C. Thummel, M. Beato, P. Herrlich, G. Schutz, K. Umesono, B. Blumberg, P. Kastner, M. Mark, P. Chambon, and R. M. Evans. 1995. The nuclear receptor superfamily: the second decade. Cell 83, 835-839.

24. McKenna, N. J., R. B. Lanz, and B. W. O'Mally. 1999. Nuclear receptor coregulators; cellular and molecular biology. Endocr. Rev. 20, 321-344.

25. McLellan, A. S., T. Kealey, and K. Langlands. 2006. An E box in the exon 1 promoter regulates insulin-like growth factor-I expression in differentiating muscle cells. Am J. Physiol. 291, C300-C307.

26. Meng, D., X. Shi, B. H. Jiang, and J. Fang. 2007. Insulin-like growth factor-I (IGF-I) induces epidermal growth factor receptor transactivation and cell proliferation through reactive oxygen species. Free Radic. Biol. Med 42, 1651-1660.

27. Park, P. and P. Cohen. 2005. Insulin-like growth factor I (IGF-I) measurements in growth hormone (GH) therapy of idiopathic short stature (ISS). Growth Horm IGF Res. 15, S13-20.

28. Powell, S. M., V. Christiaens, D. Voulgaraki, J. Waxman, F. Claessens, and C. L. Bevan. 2004. Mechanisms of androgen receptor signalling via steroid receptor coactivator-1 in prostate. Endocr. Relat. Cancer 11, 117-130.

29. Rahman, M. M., H. Miyamoto, H. Takatera, S. Yeh, S. Altuwaijri, and C. Chang. 2003. Reducing the agonist activity of anti-androgens by a dominant-negative androgen receptor coregulator ARA70 in prostate cancer cells. J. Biol. Chem 278, 19619-19626.

30. Roy, A. K., R. K. Tyagi, C. S. Song, Y. Lavrovsky, S. C. Ahn, T. S. Oh, and B. Chatterjee. 2001. Androgen receptor:

structural domains and functional dynamics after ligand-receptor interaction. Ann. NY. Acad Sci. 949, 44-57.

31. Siriett, V., G. Nicholas, C. Berry, T. Watson, A. Hennebry, M. Thomas, N. Ling, M. Sharma, and R. Kambadur. 2006. Myostatin negative regulates the expression of the steroid receptor co-factor ARA70. J. Cell Physiol. 206, 255-263.

32. Suzuki, H., T. Ueda, T. Ichikawa, and H. Ito. 2003. Androgen receptor involvement in the progression of prostate cancer. Endocr. Relat. Cancer 10, 209-216.

33. Takeshita, A., G. R. Cardona, N. Koibuchi, C. S. Suen, and W. W. Chin. 1997. TRAM-1, A novel 160-kDa thyroid hormone receptor activator molecule, exhibits distinct properties from steroid receptor coactivator-1. J. Biol. Chem 272, 27629-27634.

34. Touno, M., M. Senda, K. Nakago, Y. Yokoyama, and H. Inoue. 1996. Muscle fiber changes of the vastus medialis in rheumatoid patients. Acta. Medica. Okayama. 50, 157-164.

35. Ueda, T., D. T. Max, N. Bruchovsky, and M. D. Sadar. 2002. Ligand-independent activation of the androgen receptor by interlukin- 6 and the role of steroid receptor coactivator-1 in prostate cancer cells. J. Biol. Chem 277, 38087-38094.

36. Wu, Z., P. J. Woodring, K. S. Bhakta, K. Tamura, F. Wen, J. R. Feramisco, M. Karin, J. Y. Wang, and R. L. Puri. 2000. p38 and extra cellular signal regulated kinases regulate the myogenic program at multiple steps. Mol. Cell Endocrinol. 20, 3951-3964.

37. Xu, L., C. K. Glass, and M. G. Rosenfeld. 1999. Coactivator and corepressor complexes in nuclear receptor function. Curr. Opin. Gent. Dev. 9, 140-147.

38. Yeh, S. and C. Chang. 1996. Cloning and characterization of a specific coactivator, ARA70, for the androgen receptor in human prostate cells. Proc. Natl. Acad Sci. USA. 93, 5517-5521.

39. Zester, A., E. Gredinger, and E. Bengal. 1999. p38 mitogen-activated protein kinase pathway promotes skeletal muscle differentiation. Participation of the Mef2c transcription factor. J. Biol. Chem. 274, 5193-5200. 
초록: $\mathrm{C} 2 \mathrm{C} 12$ 세포에서 insulin-like growth factor-100 p38 MAPK, ERK1/2 신호전달 경로를 통 해 엔드로젠 수용체 coactivator 발현에 미치는 영향

박찬호 ${ }^{2} \cdot$ 김혜진 $^{1} \cdot$ 김태운 $^{2} \cdot$ 이원준 ${ }^{*}$ *

(이화여자대학교 건강과학대학 체육과학과, ${ }^{2}$ 부산대학교 체육교육학과)

본 연구에서는 $\mathrm{C} 2 \mathrm{C} 12$ 근육 세포에서 IGF-I이 리간드 비의존적으로 엔드로젠 수용체 coactivator 유전자 발현 에 미치는 영향에 대해 알아보았다. 그 결과 IGF-I 이 리간드 비의존적으로 엔드로젠 수용체의 coactivator인 GRIP-1, SRC-1, ARA70 유전자들의 단백질과 mRNA 발현을 증가시켰으며, p38 MAPK와 ERK1/2 신호전달 경 로 억제제인 SB203580과 PD98059를 IGF-I과 함께 처리한 결과 IGF-I에 의한 엔드로젠 수용체 coactivator 유전자 발현의 증가를 감소시켰음을 알 수 있었다. 엔드로젠 수용체 coactivator가 엔드로젠 물질이 없이도 IGF-I에 의해 발현이 증가하였다는 사실은 운동에 의해 근육에서 분비가 증가하는 IGF-I이 리간드 비의존적으로 근육 세포에 서 엔드로젠 수용체 활성화 안정에 기여하는 엔드로젠 수용체 coactivator를 활성화 시킬 수 있다는 사실을 증명 하였다는데 의의가 있다고 사료된다. 또한, IGF-I의 하부신호전달 경로로 잘 알려진 p38 MAPK와 ERK1/2 신호 전달 경로를 차단하였을 때는 발현이 억제되었는데 이를 통해 IGF-I이 근육세포 내에서 p38 MAPK, ERK1/2 경 로를 통해 엔드로젠 수용체 coactivator 발현에 중요한 역할을 한다는 사실을 확인할 수 있었다. 이러한 결과는 근육에서 중요한 기능을 담당하는 IGF-I이 엔드로젠 수용체 coactivator 유전자 발현을 조절하는 기능이 있으며 이러한 IGF-I에 의한 리간드 비의존적인 엔드로젠 수용체 coactivator 유전자 발현 조절에 있어 p38 MAPK와 $\mathrm{ERK} 1 / 2$ 는 필수적인 신호전달 경로임을 확인하였다는 데서 그 의의가 있다고 할 수 있겠다. 향후 다양한 성장인 자들에 의한 coactivator 발현에 관한 연구를 비롯하여, corepressor의 발현 억제 기능 및 신호전달 경로에 관한 연구가 추가적으로 이루어져야 할 것이다. 